\title{
Potential Use of Incineration Bottom Ash in Construction: Evaluation of the Environmental Impact
}

\author{
Ute Kalbe $^{1}$ [D $\cdot$ Franz-Georg Simon ${ }^{1}$ (D)
}

Received: 2 May 2019 / Accepted: 4 May 2020 / Published online: 14 May 2020

(C) The Author(s) 2020

\begin{abstract}
Knowledge of the long-term leaching behavior of potentially harmful substances is crucial for the assessment of the environmental compatibility of reusing municipal solid-waste incineration bottom ash (MSWI BA) in construction, i.e., as a road base layer. BA fractions obtained from wet-processing aiming at the improvement of environmental quality were used to investigate the mobility of relevant substances. Eluates from laboratory-scaled leaching procedures (column percolation and lysimeters) were analyzed to learn about the long-term release of substances. Unsaturated conditions and artificial rainwater (AR) were used in the lysimeter tests to simulate field conditions. In addition, batch test eluates were generated at usual liquid-to-solid ratios (L/S) for compliance testing purposes. A variety of cations and anions was measured in the eluates. The wet treatment reduces the leaching of chloride and particularly sulfate by more than $60 \%$. The release of typical contaminants for the treated MSWI BA such as the heavy metals $\mathrm{Cu}$ and $\mathrm{Cr}$ was well below $1 \%$ in the conducted leaching tests. An increase in the $\mathrm{Sb}$ concentration observed in the lysimeter experiments starting at $\mathrm{L} / \mathrm{S} 0.75 \mathrm{~L} / \mathrm{kg}$ and in the column experiment at $\mathrm{L} / \mathrm{S} 4 \mathrm{~L} / \mathrm{kg}$ is assumed to be related to decreasing concentrations of $\mathrm{Ca}$ and thus to the dissolution of sparingly soluble calcium antimonate. The same leaching mechanism applies with $\mathrm{V}$, but the concentration levels observed are less critical regarding relevant limit values. However, on the long term the behavior of Sb could be problematic for the application of MSWI BA in construction.
\end{abstract}

\section{Graphic Abstract}

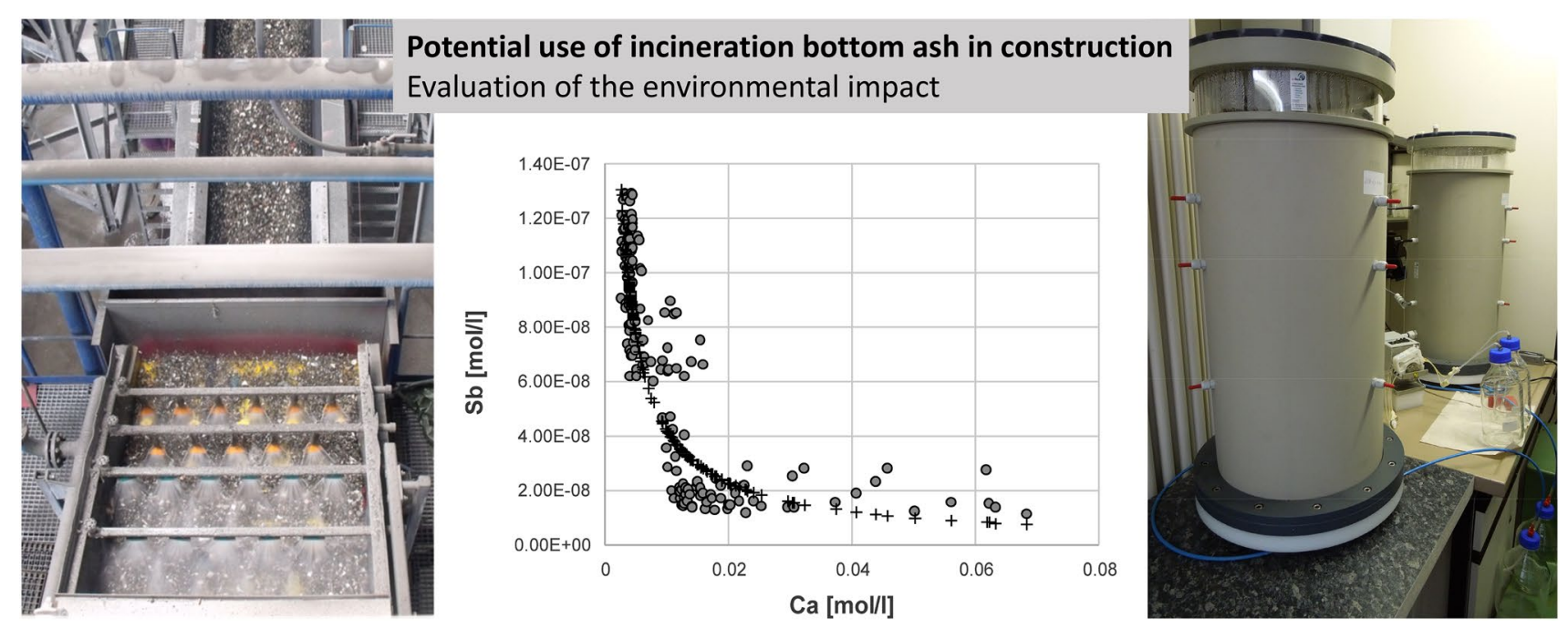

Electronic supplementary material The online version of this article (https://doi.org/10.1007/s12649-020-01086-2) contains supplementary material, which is available to authorized users.

Extended author information available on the last page of the article 
Keywords MSWI bottom ash $\cdot$ Leaching $\cdot$ Batch tests $\cdot$ Lysimeter $\cdot$ Antimony

\section{Statement of Novelty}

Wet-mechanical treatment is an option to generate secondary raw material from waste incineration residues with high quality regarding environmental compatibility as a surrogate in construction. Especially from long-term lysimeter tests with treated bottom ash, the leaching behavior of such materials was investigated for almost 5 years using fieldlike conditions. Particularly the unusual leaching behavior of antimony was shown and related to the immobilization of calcium, i.e. increasing antimony concentrations with proceeding ageing. This phenomenon must generally be observed when bottom ash is applied in construction since threshold values might be exceeded in a later stage of lifetime. The findings will induce research on suitable countermeasures to avoid environmental burden.

\section{Introduction}

Approximately 68 million tonnes of municipal solid waste (about 27\% of total amount) were incinerated in 2017 in the EU-28 countries [1] which resulted in about 15 million tonnes of MSWI BA and represents a valuable source for secondary raw materials. After separation of metals the remaining mineral fraction is mostly reused as unbound aggregate for construction of road base layers. Even though, the environmental behavior of MSWI BA in reuse scenarios in construction has been intensively studied [2-7], there is still a substantial need for research e.g. regarding advanced pre-treatment options to improve the mechanical performance, to reduce the environmental impact and finally to save natural resources as well as landfill space.

In Germany, the regulations on the reuse of mineral waste are in the responsibility of the 16 Federal states so far. Quite stringent threshold values for substances of environmental concern (including $\mathrm{Sb}$ ) are targeted to be regulated on national level [8]. Even though, harmonized leaching procedures are required by the European Commission [9] and are being developed (e.g. [10]) on European level not all European member states have implemented appropriate regulations. Further, the specification of threshold values remains in the responsibility of the member states so far. Therefore, the risk assessment approaches are different even in countries with well-developed legislation [11].

Considering the waste input [12], operational conditions of incineration [13] and pre-treatment technologies [14-16], the subsequent influence on the leaching behavior has to be investigated to assess a potential environmental risk in reuse applications [17]. Furthermore, a comparison of data obtained by simple laboratory tests to data obtained under field conditions is of high interest for this purpose [18-20].

A wet-processing technology for municipal solid waste incineration bottom ash (MSWI BA) has been optimized regarding the amount and quality of the fractions produced in the framework of a project funded by ZIM (Central Innovation Program for SMEs of German Federal Ministry for Economic Affairs and Energy). The technology focuses on the mineral fractions, which are the main mass fraction, in order to enable their reuse as construction products. In particular, the aim was the removal of chloride and the transfer of sulfate to the finest fraction. Within the project, we performed accompanying investigations regarding the mass balance of the process and the leaching behavior of the various processed fractions [21].

In this manuscript, eluate analyses from batch leaching, column percolation, and lysimeter tests in laboratory scale were thereby discussed to learn more about the long-term release of hazardous substances from bottom ash in civil engineering applications, e.g. road construction [2, 22].

Particularly, attention was paid on the potentially critical leaching behavior of Sb which is mainly introduced to bottom ash from additives in plastics. The specific behavior of antimony in MSWI BA has been discussed by previous studies [20, 23-26]. It is intended to regulate $\mathrm{Sb}$ in MSWI BA in Germany within a new ordinance on the reuse of mineral waste $[8,27]$.

\section{Experiment}

\section{Material}

The material was sampled on November 5, 2013 at a bottom ash treatment plant in Germany. Ferrous $(\mathrm{Fe})$ and non-ferrous (NFe) metals had already been removed by standard methods (magnets, eddy current separation). A wetmechanical process step was implemented in the plant to remove the finest fraction below $0.25 \mathrm{~mm}$ [21]. Two mineral fractions $(0.25-4 \mathrm{~mm}$ and $4-60 \mathrm{~mm})$ were generated by different sieving steps (see Fig. 1).

The mineral fractions from $0.25-4$ to $4-60 \mathrm{~mm}$ were sampled, air-dried, and homogenized separately. The 4-60 $\mathrm{mm}$ fraction was additionally sieved to $45 \mathrm{~mm}$. Representative subsamples of both fractions were then combined in the lab at a ratio of 40:60 to the final $0.25-45 \mathrm{~mm}$ test material employed for the leaching experiments, since this condition was expected as the status on an intermittent storage site before reuse of such material. 


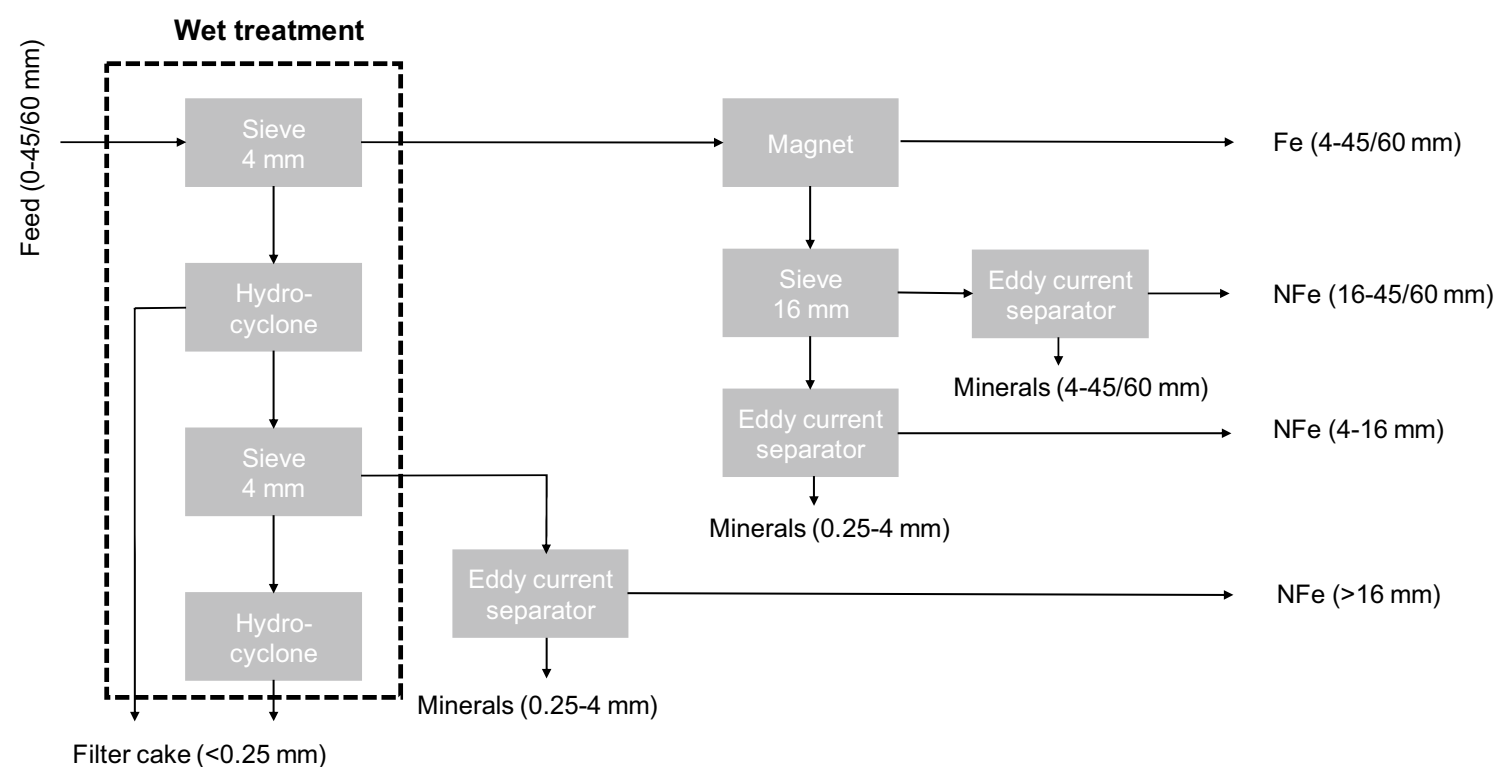

Fig. 1 Sketch of the wet treatment process for MSWI bottom ash (Fe and NFe are ferrous and non-ferrous metals)

Samples from the filter cake (fraction below $0.25 \mathrm{~mm}$ ) separated in a chamber filter press were also sampled.

The particle density of the mixed material was determined by means of helium pycnometry (AccuPyc, micromeritics) [28]. The moisture content was measured by drying at 105 ${ }^{\circ} \mathrm{C}$ following DIN EN 14346. Loss on ignition was determined by heating the pre-dried sample $\left(12 \mathrm{~h}\right.$ at $\left.105^{\circ} \mathrm{C}\right)$ for $4 \mathrm{~h}$ at $550{ }^{\circ} \mathrm{C}$ [29].

Size-reduced subsamples were acid-digested in a microwave oven ( $\mu$ PREP-A, MLS GmbH, Leutkirch, Germany) according to DIN ISO 11466 [30] to analyze the total contents of metals. Such samples were also subjected to a carbonate determination following the principles of DIN EN ISO 10693 [31] and using a special apparatus (D. Klosa, Hambühren) with pressure sensors to measure the $\mathrm{CO}_{2}$ development. Chloride and sulfate were analyzed after aqueous extraction with an excess of sodium carbonate.

\section{Leaching Tests}

With the test material described in 2.1, four different leaching tests were performed: (i) a lysimeter test up to a liquidto-solid ratio (L/S) of $2.96 \mathrm{~L} / \mathrm{kg}$, (ii) a column test up to $\mathrm{L} / \mathrm{S}=9.6 \mathrm{~L} / \mathrm{kg}$, and (iii) batch tests using a $\mathrm{L} / \mathrm{S}$ (iii) 2 and (iv) $10 \mathrm{~L} / \mathrm{kg}$.

Two laboratory scale lysimeters (polypropylene cylinders, $30 \mathrm{~cm}$ in diameter, $57.5 \mathrm{~cm}$ in height, ecoTech $\mathrm{GmbH}$, Bonn) were assembled in March 2014 and are still being operated. Approximately $60 \mathrm{~kg}$ of test material (59.3 kg dry mass) was introduced to each of the lysimeters in layers. The resulting bulk density of the sample in the lysimeters was $1.46 \mathrm{~g} / \mathrm{cm}^{3}$; the corresponding porosity was $45 \%$; and one pore volume amounts to $18.4 \mathrm{~L}$.

A quartz sand layer of $2 \mathrm{~cm}$ (1-2 mm particle size) was put on top of the test material to facilitate the distribution of irrigation done by a system of needles fed from a storage bottle by a peristaltic pump. Artificial rainwater (AR) is used as leachant (pH 6, see Table S1) [32]. The lysimeters were operated under unsaturated condition and irrigated once a week with $816 \mathrm{~mL}$ leachant, corresponding to an average annual precipitation rate of $600 \mathrm{~mm} / \mathrm{a}$, leading to a liquid-to-solid ratio $(\mathrm{L} / \mathrm{S})$ of about $0.7 \mathrm{~L} / \mathrm{kg}$ per year of operation. The day of the irrigation events each week was chosen randomly within working days. A $0.45 \mu \mathrm{m}$ polyamide membrane was placed at the bottom of the lysimeters. Leachates were sampled every two weeks. Inserted sensors measured temperature, $\mathrm{pH}$, and redox potential in-line. The duration of the experiment to the time of writing this paper was $37,296 \mathrm{~h}$ (more than 4 years); complete analyses of the leachates were performed with 110 different L/S ratios ranging from 0.02 to 2.96 .

A tracer was used between L/S 1.9 and 2.7 to check the generation of possible preferential pathways during the lysimeter experiments. For this purpose, $\mathrm{KBr}$ substituted $\mathrm{KCl}$ in the AR leachant (see Table S1 in the supporting material of this publication). The concentration of $\mathrm{Br}$ in the leachant was $1000 \mathrm{mg} / \mathrm{L}$. About $48 \mathrm{~L}$ of the leachant with bromide permeated through the lysimeters during this period, whereby about 2.6 pore volumes were intended to be exchanged. This period is called "tracer experiment" in the following.

Laboratory column percolation tests were performed according to DIN 19528 [33]. The inner diameter of the 
Borosilicate glass columns was $10 \mathrm{~cm}$, the filling height $40 \mathrm{~cm}$, and the resulting sample dry mass approximately $4.9 \mathrm{~kg}$ for all columns. The porosity of the material packed in the columns was $42 \%$. Following DIN 19528, a flow rate of $4.35 \mathrm{~mL} / \mathrm{min}$ was applied to obtain $5 \mathrm{~h}$ contact time between leachant and sample. Whereas such column percolation tests are usually performed up to an $\mathrm{L} / \mathrm{S}$ of $4 \mathrm{~L} / \mathrm{kg}$, the tests in this study were extended to an $\mathrm{L} / \mathrm{S}$ of approximately $10 \mathrm{~L} / \mathrm{kg}$ to make it possible to compare the release of substances with the other leaching tests and especially to study the long-term behavior of Sb. In contrast to the lysimeter experiments, saturated conditions prevailed in the laboratory column tests. The duration of the column experiment was $186 \mathrm{~h}$. The use of Milli-Q water as leachant is standard for this type of test. In addition, artificial rainwater (AR) was used to make it possible to compare with the lysimeter results.

Batch tests were performed according to DIN 19529 [34] (L/S 2 L/kg) and DIN EN 12457 [35] (L/S 10 L/kg). A representative sample mass of approximately $2.5 \mathrm{~kg}$ for each test was split into several subsamples, which were shaken in several glass bottles for $24 \mathrm{~h}$. After $15 \mathrm{~min}$ of settling, the supernatants were recombined. Pressure filtration was subsequently conducted through a $0.45-\mu \mathrm{m}$ cellulose nitrate membrane filter for liquid-solid separation. All leaching tests were performed in at least duplicates.

\section{Analysis of Heavy Metals and Anions in Eluates}

Leachates were aliquoted after sampling. A small subsample was analyzed immediately for conductivity, $\mathrm{pH}$, turbidity, and total organic carbon (TOC) as basic parameters. For chemical analysis, one aliquot was preserved using concentrated nitric acid [36] for measurement of cations, and one aliquot remained untreated for anion analysis. The eluates were stored at $4{ }^{\circ} \mathrm{C}$ until measurement.

TOC concentration was determined with a TOC-VCPH analyzer (Shimadzu, Berlin, Germany) by the difference method with external calibration. $\mathrm{pH}$ values were measured with a Schott CG $841 \mathrm{pH}$-meter equipped with a WTW SenTix $41 \mathrm{pH}$ electrode [37], the electric conductivity with a WTW LF 437 microprocessor conductivity meter [38], and turbidity by a HACH $2100 \mathrm{~N}$ turbidity meter [39].

Cations (Al, As, Ba, Ca, Cd, Co, Cr, Cu, Fe, $\mathrm{Hg}, \mathrm{K}, \mathrm{Mg}$, $\mathrm{Mn}, \mathrm{Mo}, \mathrm{Na}, \mathrm{Ni}, \mathrm{Pb}, \mathrm{Sb}, \mathrm{Sn}, \mathrm{Sr}, \mathrm{V}, \mathrm{Zn}, \mathrm{Se}$ ) were quantified on an iCAP 7000 ICP-OES equipped with an ASX-260 autosampler (Thermo Scientific, Dreieich) according to [40]. An external calibration with mixed standards was carried out for the ICP-OES. Anions $\left(\mathrm{F}^{-}, \mathrm{Cl}^{-}, \mathrm{NO}_{3}{ }^{-}, \mathrm{Br}^{-}, \mathrm{NO}_{2}^{-}\right.$, $\mathrm{PO}_{4}{ }^{3-}, \mathrm{SO}_{4}{ }^{2-}$ ) were determined on an IC320 ion chromatograph with an AS 40 autosampler, an ASRS 300 suppressor, an AS-9-HC separation column with column oven, and a conductivity detector according to DIN EN ISO 10304 [41]. The separation was isocratic with a mixture of carbonate/ bicarbonate in aqueous solution $(8 \mathrm{mmol} / \mathrm{L} / 1 \mathrm{mmol} / \mathrm{L})$ as eluent. ICP-MS measurements were performed from tenfold dilutions with a Thermo Scientific iCAP Qc [42].

\section{Results and Discussion}

\section{Mass Balance of the Process}

The objectives of the wet treatment process for MSWI bottom ash were to produce higher quality mineral material for use as secondary building material and the recovery of the purest possible metals. Therefore, the treatment was executed without prior ageing of the bottom ash. The process was realized in two plants in Germany, one near a waste incineration plant and a second where the ash material was delivered by combined ship and truck transport. The capacity was in the range of 50-60 tons per hour. Details of the process are described elsewhere [21]. A sketch of the process is displayed in Fig. 1.

The mass balance was estimated over an 8-month operation period in which more than 65,000 tons were treated. The results are displayed in Table 1.

The intended use as secondary building material was targeted in a ratio of $60 \%$ fine and $40 \%$ coarse mineral material by the operator of the recycling plant in order to obtain the desired sieving line and improve the soilmechanical characteristics. All analyses and leaching experiments in the present study were therefore performed with a 60:40 mixture of the two fractions. However, the mass balance for sulfate was estimated with the analyses of the separate fractions. With the data in Table 1, it can be calculated that $60.4 \%$ of the sulfate input is concentrated in the filter cake $\left(123,500 \mathrm{mg} \mathrm{SO}_{4} / \mathrm{kg} \times 12.2 \%\right) /(24,966 \mathrm{mg}$ $\mathrm{SO}_{4} / \mathrm{kg}$ ), see Table 1. Chloride can be removed from the initial material only by dissolution and not by separation of a certain grain-size fraction and is therefore dependent on the frequency of washing water renewal.

Table 1 Mass balance of the wet treatment process

\begin{tabular}{llc}
\hline Fraction & Share $(\%)$ & Sulfate $(\mathrm{mg} / \mathrm{kg})$ \\
\hline Filter cake $(<0.25 \mathrm{~mm})$ & 12.2 & 123,500 \\
Fine aggregates $(0.25-4 \mathrm{~mm})$ & 30.7 & 17,800 \\
Coarse aggregates $(4-60 \mathrm{~mm})$ & 53.8 & 6800 \\
Fine non-ferrous metals $(0.25-4 \mathrm{~mm})$ & 0.03 & \\
Medium non-ferrous metals $(4-16 \mathrm{~mm})$ & 0.9 & \\
Coarse non-ferrous metals $(>16 \mathrm{~mm})$ & 0.7 & \\
Fine ferrous metals (nails, bolts, caps, & 1.7 & \\
$\quad$ etc.) & & 24,966 \\
Total & 100 & \\
\hline
\end{tabular}




\section{Bulk Parameters}

For numerous elements, the $\mathrm{pH}$ value is the dominant factor controlling the solubility [43]. Wet extracted bottom ash exhibits $\mathrm{pH}$ values above 12 before start of the ageing processes (e.g. formation of $\mathrm{CaCO}_{3}$ from the reaction of $\mathrm{Ca}(\mathrm{OH})_{2}$ with $\mathrm{CO}_{2}$ from the air transported by rainwater). From the solubility of $\mathrm{Ca}(\mathrm{OH})_{2}$, a maximum $\mathrm{pH}$ value of 12.2 can be calculated. At such high pH values, high concentrations of certain heavy metals can be measured in standard leaching tests. Lead, for example, forms soluble hydroxy complexes $\left(\mathrm{Pb}(\mathrm{OH})_{4}{ }^{2-}\right)$, resulting in concentrations above $0.2 \mathrm{mg} / \mathrm{L}$ in batch tests with $\mathrm{L} / \mathrm{S}=10 \mathrm{~L} / \mathrm{kg}$ [44]. Below $\mathrm{pH}$ 12 , the concentrations are considerably lower. In the present work, the $\mathrm{pH}$ value was below 12 in all experiments after reaching equilibrium conditions $(\mathrm{L} / \mathrm{S}>0.21 \mathrm{~L} / \mathrm{kg})$, see Fig. 2.

In the batch test at $\mathrm{L} / \mathrm{S}=2 \mathrm{~L} / \mathrm{kg}$ and $\mathrm{L} / \mathrm{S}=10 \mathrm{~L} / \mathrm{kg}$, only the final $\mathrm{pH}$ values can be recorded (10.6 for $\mathrm{L} / \mathrm{S} 2$ and 10.7 for L/S 10).

Redox potential was measured continuously in the lysimeter experiment and was in the range of $20-40 \mathrm{mV}$. The electrical conductivity dropped from maximum values above $20,000 \mu \mathrm{S} / \mathrm{cm}$ in the beginning by more than $90 \%$ to values well below $2000 \mu \mathrm{S} / \mathrm{cm}$.

\section{Total Content of MSWI BA Constituents}

Table 2 shows the total content of substances in the bottom ash samples used for the leaching experiments. The total content of the finest fraction that was removed by the wet-mechanical process step in the BA treatment plant is displayed in Table 2 for comparison. Noticeable is the considerably higher content of $\mathrm{Ca}$ and sulfate in the filter cake. Enrichment by other elements such as $\mathrm{Pb}$ and $\mathrm{Sb}$ might
Table 2 Total content of substances in the test material in $\mathrm{mg} / \mathrm{kg}$

\begin{tabular}{|c|c|c|}
\hline Substance & $\begin{array}{l}\text { Treated bottom ash } \\
0.25-45 \mathrm{~mm}\end{array}$ & $\begin{array}{l}\text { Filter cake } \\
<0.25 \mathrm{~mm}\end{array}$ \\
\hline $\mathrm{Al}$ & $36,310.0$ & $35,415.0$ \\
\hline As & 4.3 & 7.3 \\
\hline $\mathrm{Ba}$ & $1,725.6$ & 646.0 \\
\hline $\mathrm{Ca}$ & $90,678.4$ & $162,725.0$ \\
\hline $\mathrm{Cd}$ & 4.6 & 8.9 \\
\hline Co & 64.1 & 34.8 \\
\hline $\mathrm{Cr}$ & 436.9 & 270.1 \\
\hline $\mathrm{Cu}$ & 3725.0 & 2654.0 \\
\hline $\mathrm{Fe}$ & $57,188.2$ & $28,185.0$ \\
\hline K & 2414.0 & 1826.0 \\
\hline $\mathrm{Mg}$ & 7694.4 & 8670.0 \\
\hline $\mathrm{Mn}$ & 1098.2 & 723.0 \\
\hline Mo & 18.4 & 20.6 \\
\hline $\mathrm{Na}$ & 6770.8 & 3054.0 \\
\hline $\mathrm{Ni}$ & 249.3 & 147.1 \\
\hline $\mathrm{Pb}$ & 1062.4 & 1583.0 \\
\hline $\mathrm{Sb}$ & 47.9 & 103.7 \\
\hline Sn & 40.1 & 50.2 \\
\hline $\mathrm{Sr}$ & 293.0 & 452.0 \\
\hline V & 56.2 & 58.4 \\
\hline $\mathrm{Zn}$ & 3413.4 & 4770.0 \\
\hline $\mathrm{Cl}$ & 2840.0 & 6700.0 \\
\hline $\mathrm{SO}_{4}$ & $13,400.0$ & $123,500.0$ \\
\hline $\mathrm{CO}_{3}$ & $33,140.0$ & \\
\hline
\end{tabular}

not be significant, due to the common inhomogeneity of MSWI BA. However, at least the wet-mechanical process successfully reduced the sulfate content in the mineral fraction above $0.25 \mathrm{~mm}$ foreseen for use (Table 1), since a high portion of sulfate is transferred to the filter cake (Table 2).
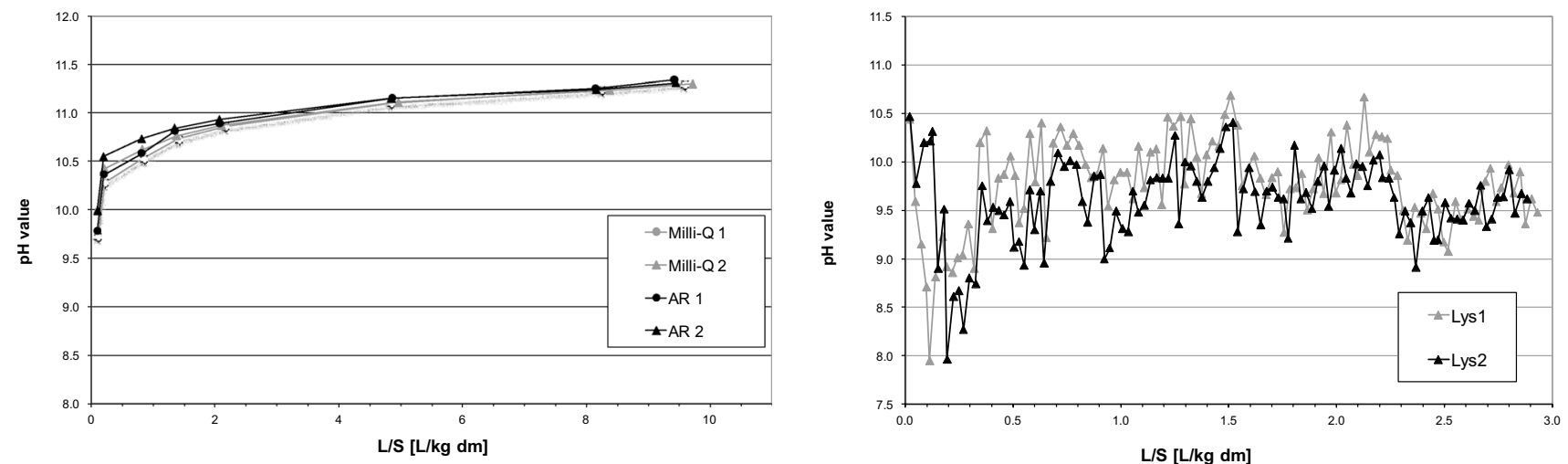

Fig. $2 \mathrm{pH}$ value as a function of the L/S ratio in the column experiments using MilliQ and AR as eluent (left, two replicates each) and the lysimeter experiment (right, two replicates) 


\section{Release of Contaminants}

The irrigation scheme resulted in unsaturated conditions in the lysimeters. Since the day of weekly irrigation changes randomly, the collected eluate volume in the 2-week sampling periods fluctuated, too. The collected eluate volume was $1568 \pm 226 \mathrm{~mL}$ on average for both lysimeters in all the experiments, i.e., it took approximately 12 weeks (12 irrigation and 6 sampling events) and an L/S span of about 0.16 to exchange one pore volume $(18.4 \mathrm{~L})$.

It turned out during the period of the tracer experiment that the well measurable breakthrough $\left(\mathrm{c} / \mathrm{c}_{0}>0.1\right)$ of the bromide tracer took a span of 5 sampling events and 0.13 difference in the $\mathrm{L} / \mathrm{S}$.

The bromide concentration then increased to a maximum of about $870 \mathrm{mg} / \mathrm{L}$ after an L/S difference of 0.73 or after exchanging about 2.4 pore volumes. The full concentration of bromide in the leachant was not measured in the eluates, probably due to sorption to the sample. After switching back to the original composition of the AR (see Table S1), the bromide concentration decreased again, but was still enhanced (approximately $270 \mathrm{mg} / \mathrm{L}$ ) after an L/S difference of 0.2 (i.e., definitely more than one pore volume) at the time of writing this manuscript. Overall, the tracer experiment allows us to assume that no significant preferential pathways existed throughout the lysimeter experiments.

The release of contaminants in the four conducted leaching tests was generally low and above $1 \%$ only for the alkaline or alkaline earth elements $\mathrm{Na}, \mathrm{K}, \mathrm{Ca}$, and $\mathrm{Sr}$, as well as for the anions chloride and sulfate, see Table 3. Although the same initial material was used in all leaching experiments, the release of contaminants differs for some substances considerably, e.g. $\mathrm{Al}, \mathrm{Cr}, \mathrm{Sb}, \mathrm{Sn}$, and $\mathrm{Zn}$. But the variation is not significant (max. value/min. value $<2$ ) for $\mathrm{Ca}, \mathrm{Cu}, \mathrm{K}$, $\mathrm{Na}, \mathrm{Sr}$, and sulfate. All the results from the four leaching tests are displayed in Fig. 3. Plotting all data in a $\log / \log$ diagram resulted in a fitted straight line with a slope of 1.09 and an intercept of $2.89\left(\mathrm{y}=0.0013 \mathrm{x}^{1.09}\right.$, with $\mathrm{y}=$ release and $x=$ total content) with a fair correlation of $48 \%$, see the dotted line in Fig. 3. This behavior proves that all that can be predicted from the content is the magnitude of the release of a certain element. Similar findings were obtained in the work of Yin et al. [45]. Their correlation was in the range of 50\% with somewhat lower slopes and intercepts. However, the authors performed leaching experiments at a $\mathrm{L} / \mathrm{S}$ ratio of 10 $\mathrm{L} / \mathrm{kg}$ ) only, at natural $\mathrm{pH}$ and several other static $\mathrm{pH}$ values.

In batch tests, it is not possible to obtain any information on the time-dependent release of a certain element, i.e., the
Table 3 Release of contaminates with incineration bottom ash in four different leaching tests

\begin{tabular}{|c|c|c|c|c|c|c|}
\hline \multicolumn{2}{|c|}{$\begin{array}{l}\text { Bottom ash } \\
(0.25-60 \mathrm{~mm})\end{array}$} & \multirow{2}{*}{$\begin{array}{l}\mathrm{L} / \mathrm{S} 2 \mathrm{~L} / \mathrm{kg} \\
\text { batch test } \\
\% \text { release }\end{array}$} & \multirow{2}{*}{$\begin{array}{l}\mathrm{L} / \mathrm{S} 2.96 \mathrm{~L} / \mathrm{kg} \\
\text { lysimeter } \\
\% \text { release }\end{array}$} & \multirow{2}{*}{$\begin{array}{l}\mathrm{L} / \mathrm{S} 9.6 \mathrm{~L} / \mathrm{kg} \\
\text { column test } \\
\% \text { release }\end{array}$} & \multirow{2}{*}{$\begin{array}{l}\mathrm{L} / \mathrm{S} 10 \mathrm{~L} / \mathrm{kg} \\
\text { batch test } \\
\% \text { release }\end{array}$} & \multirow[t]{2}{*}{ Min./max. } \\
\hline Content & $\mathrm{mg} / \mathrm{kg}$ & & & & & \\
\hline $\mathrm{Al}$ & $36,310.0$ & 0.003 & 0.004 & 0.075 & 0.182 & 50.7 \\
\hline As & 4.3 & 0.627 & 0.006 & 0.233 & & 102.3 \\
\hline $\mathrm{Ba}$ & 1725.6 & 0.013 & 0.009 & 0.033 & 0.181 & 20.5 \\
\hline $\mathrm{Ca}$ & $90,678.4$ & 1.702 & 1.467 & 2.364 & 2.161 & 1.5 \\
\hline $\mathrm{Cd}$ & 4.6 & & 0.002 & 0.009 & & 3.9 \\
\hline Co & 64.1 & & 0.076 & & & \\
\hline $\mathrm{Cr}$ & 436.9 & 0.002 & 0.010 & 0.055 & 0.032 & 5.8 \\
\hline $\mathrm{Cu}$ & 3725.0 & 0.008 & 0.006 & 0.009 & 0.008 & 1.5 \\
\hline $\mathrm{Fe}$ & $57,188.2$ & $4.984 \mathrm{E}-04$ & $9.439 \mathrm{E}-05$ & $1.399 \mathrm{E}-05$ & & 35.6 \\
\hline K & 2414.0 & 5.074 & 11.144 & 7.144 & 13.422 & 2.6 \\
\hline $\mathrm{Mg}$ & 7694.4 & 0.018 & 0.003 & 0.010 & 0.019 & 6.0 \\
\hline $\mathrm{Mn}$ & 1098.2 & & 0.000 & 0.000 & & 1.8 \\
\hline Mo & 18.4 & 3.824 & 1.014 & 4.977 & & 4.9 \\
\hline $\mathrm{Na}$ & 6770.8 & 5.338 & 6.947 & 4.943 & 9.216 & 1.4 \\
\hline $\mathrm{Ni}$ & 249.3 & & 0.006 & 0.033 & & 5.3 \\
\hline $\mathrm{Pb}$ & 1062.4 & & $4.560 \mathrm{E}-05$ & & & \\
\hline $\mathrm{Sb}$ & 47.9 & 0.670 & 0.033 & 0.322 & 0.364 & 20.2 \\
\hline $\mathrm{Sn}$ & 40.1 & 0.419 & 0.007 & 0.202 & & 63.0 \\
\hline $\mathrm{Sr}$ & 293.0 & 2.474 & 2.530 & 3.344 & 4.355 & 1.8 \\
\hline V & 56.2 & 0.029 & 0.211 & 0.148 & & 7.2 \\
\hline $\mathrm{Zn}$ & 3413.4 & $1.172 \mathrm{E}-04$ & $1.255 \mathrm{E}-03$ & 7.617E-04 & 0.006 & 52.5 \\
\hline $\mathrm{Cl}$ & 4236.2 & 53.628 & 37.315 & 29.887 & 46.739 & 2.8 \\
\hline $\mathrm{SO}_{4}$ & 8415.9 & 29.498 & 31.474 & 46.492 & 36.359 & 1.6 \\
\hline
\end{tabular}




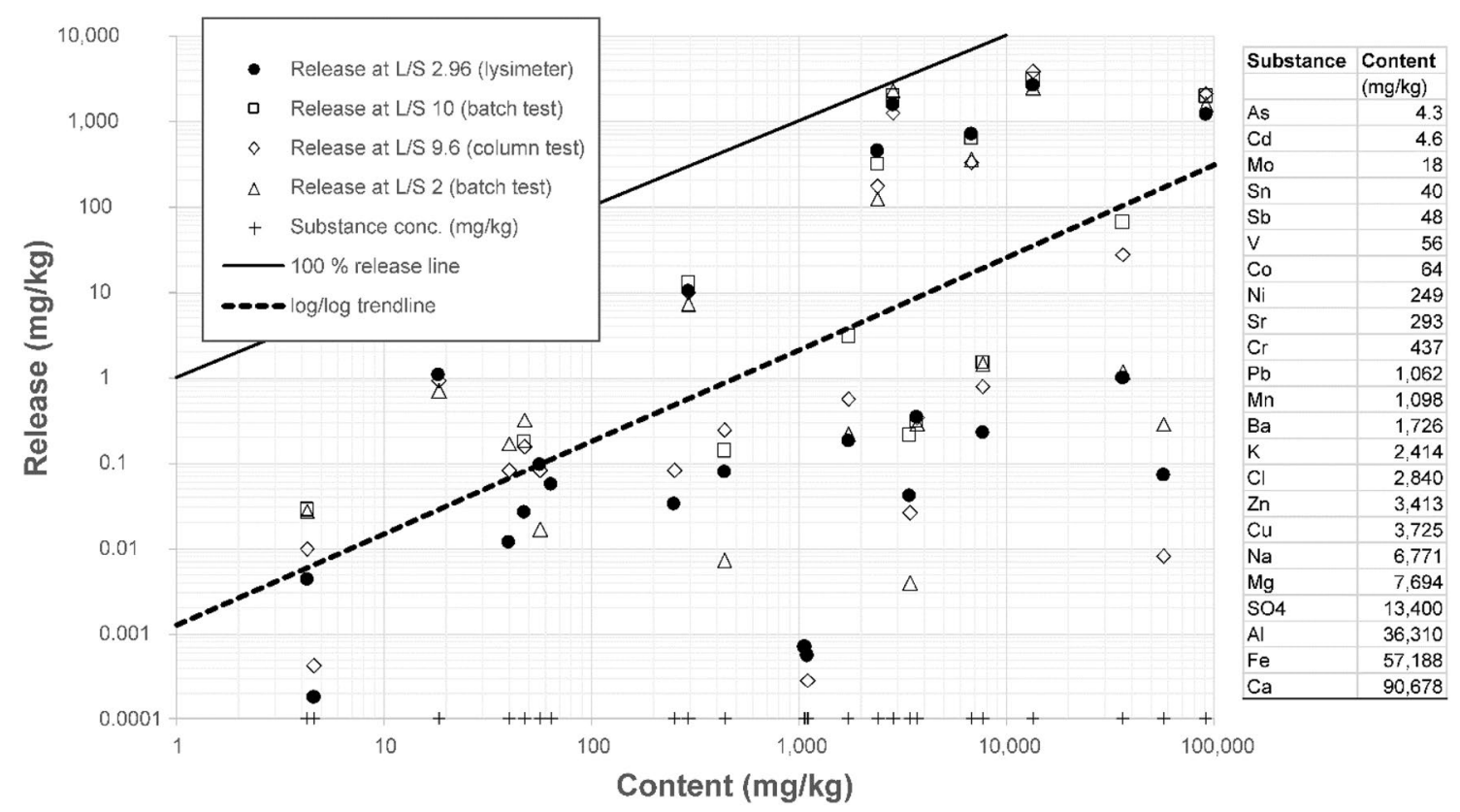

Fig. 3 Release of various cations and anions in four different leaching tests as a function of total content. There is only a fair correlation between total content and release of the respective substances

release at other $\mathrm{L} / \mathrm{S}$ ratios than that of the designated test. In column test and lysimeter investigations, leachate rates can be obtained at different $\mathrm{L} / \mathrm{S}$ ratios. Usually it is observed that the highest concentrations are measured in the beginning of the experiment at low $\mathrm{L} / \mathrm{S}$ ratios. Then the concentrations drop to lower values. This behavior is displayed in Fig. S1 (Supporting Material) for chloride and copper. The cumulative release can be calculated from the individual results by simply adding the values of the fractions. In the case of chloride, the cumulative release curve reaches an almost constant value soon, whereas for other elements the cumulative release increases on a longer time scale because the release does not approach a value close to zero [46, 47]. The concentration curves of chloride, sulfate, $\mathrm{Ca}, \mathrm{Sr}, \mathrm{Ba}, \mathrm{Cr}, \mathrm{Mo}$, $\mathrm{Cu}, \mathrm{Sb}$, and $\mathrm{V}$ for the lysimeter and column experiments, together with the curves of cumulative release, are displayed in the supporting material of this publication (Figs. S2-S5). The concentrations of the illustrated substances in the eluates were all well above the respective LOQ (limits of quantification). It can be seen in the Figs. S2 and S4 for these substances that the overall agreement between the two parallel lysimeter and column tests is quite good.

For some substances which are not illustrated the concentrations were not measurable $(\mathrm{Hg}, \mathrm{Mn})$ or very low and partly in the range of the respective LOQ which might have influenced the variance of concentrations. This applies particularly for $\mathrm{Cd}$.

In the lysimeter experiment, a considerably different behavior of antimony and vanadium was observed. The release of antimony $(\mathrm{Sb})$ was in the range of $2 \mu \mathrm{g} / \mathrm{L}$ for the first $10,000 \mathrm{~h}$ of the experiment $(\mathrm{L} / \mathrm{S}=0.8 \mathrm{~L} / \mathrm{kg})$. Then a steep increase to 10 and more $\mu \mathrm{g} / \mathrm{L}$ was observed. In the same period, the Ca concentration dropped from values around $2000 \mathrm{mg} / \mathrm{L}$ to less than $500 \mathrm{mg} / \mathrm{L}$, see Fig. 4 . The reason for this is the proceeding carbonization of the material resulting in the formation of sparingly soluble $\mathrm{CaCO}_{3}$ from better soluble $\mathrm{Ca}$ compounds such as $\mathrm{CaCl}_{2}$ or $\mathrm{Ca}(\mathrm{OH})_{2}$.

A correlation of $\mathrm{Ca}$ and $\mathrm{Sb}$ concentration was first reported for a landfill leachate by Johnson et al. [24]. According to their results, the solubility of heavy metal oxyanions such as $\mathrm{Sb}(\mathrm{OH})_{6}{ }^{-}$could be controlled by $\mathrm{Ca}$ metallates. Plotting the measured concentrations of antimony versus the $\mathrm{Ca}$ concentration reveals the direct relation, see Fig. 5. Johnson et al. proposed $\mathrm{Ca}\left(\mathrm{Sb}(\mathrm{OH})_{6}\right)_{2}$ as a solubility controlling phase [24] with a $\mathrm{Sb} / \mathrm{Ca}$ ratio of 2. However, other $\mathrm{Sb} / \mathrm{Ca}$ ratios, as well, are discussed in the literature $[23,48]$, i.e., $\mathrm{Sb} / \mathrm{Ca}=2 / 1.13$. Using the Solver module, the experimental data for $\mathrm{Sb}$ and $\mathrm{Ca}$ from the lysimeter experiments were entered in a Microsoft Excel table (EA, evolutionary algorithm) according to the following equation describing the solubility of $\mathrm{Sb}$ as a function of $\mathrm{Ca}$ :

$K_{L}=\left[\mathrm{Ca}^{2+}\right]^{m}\left[\mathrm{Sb}(\mathrm{OH})_{6}^{-}\right]^{2}$

with $\mathrm{K}_{\mathrm{L}}$ the solubility product of calcium antimonate.

The best fit resulted in a value of $5.0 \times 10^{-19}$ for $\mathrm{K}_{\mathrm{L}}$ and 1.78 for the exponent m, see Fig. 5, left. With these values, 

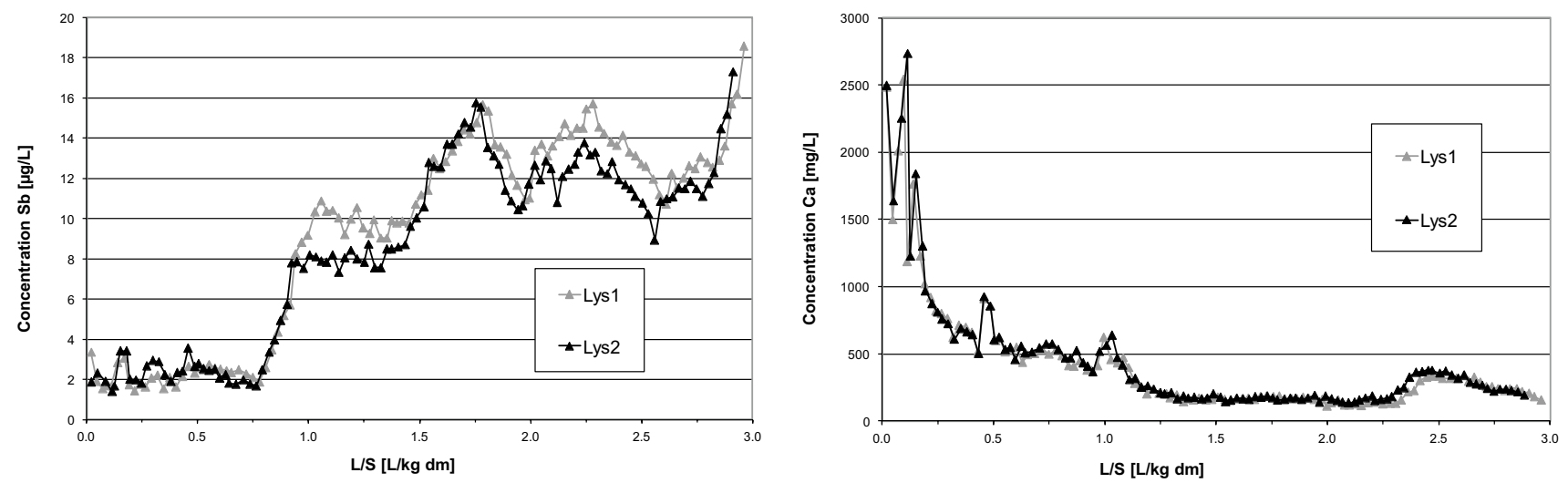

Fig. 4 Concentration of $\mathrm{Sb}$ and $\mathrm{Ca}$ as a function of the $\mathrm{L} / \mathrm{S}$ ratio
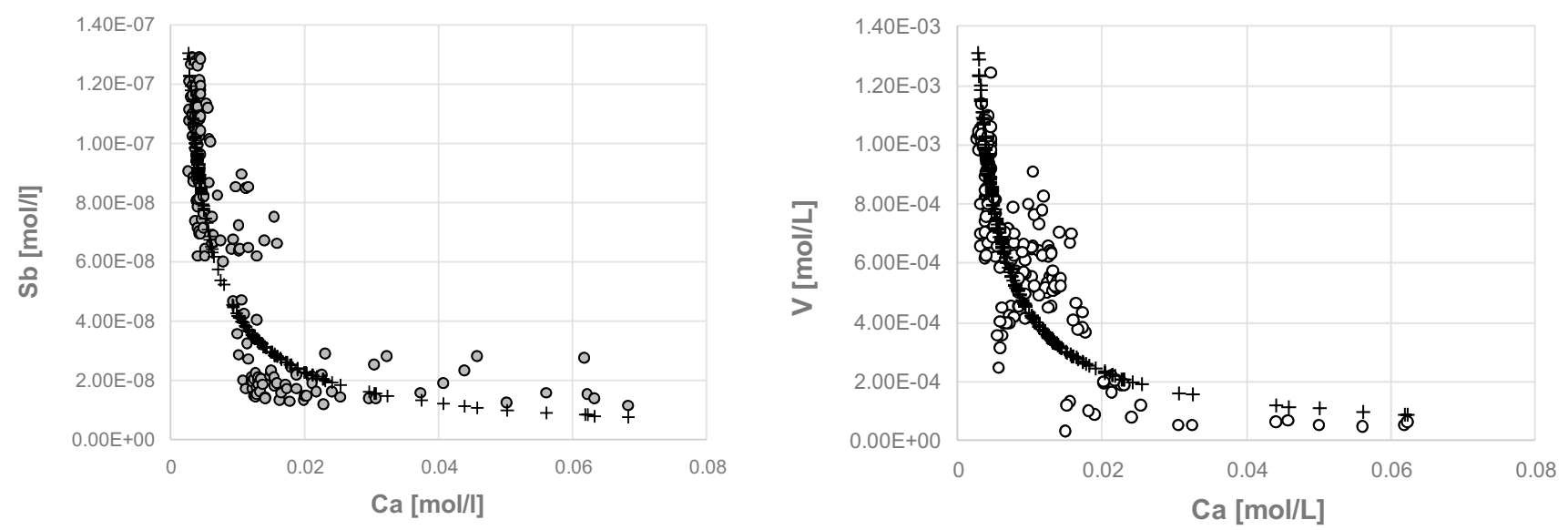

Fig. 5 Concentration of antimony and vanadium in the lysimeter experiment as a function of Ca concentration (circles). The crosses are the result of a fit, see text

the chemical formula to balance positive and negative charges would be $\mathrm{Ca}\left(\mathrm{Sb}(\mathrm{OH})_{6}\right)_{2} \times \mathrm{Ca}_{0.78}(\mathrm{OH})_{1.56}$.

Vanadium showed a comparable behavior in the lysimeter experiment, so that $\mathrm{CaV}_{2} \mathrm{O}_{6}$ could be assumed as a solubility controlling phase [49]. The best fit of the experimental data was achieved with $\mathrm{K}_{\mathrm{L}}=5.5 \times 10^{-11}$ and exponent $\mathrm{m}=1.76$, see Fig. 5, right.

$K_{L}=\left[\mathrm{Ca}^{2+}\right]^{m}\left[V_{2} \mathrm{O}_{6}\right]$

The release of antimony and vanadium from bottom ash is clearly related to the concentration of calcium, as can be seen in Fig. 5. This has already been shown for antimony in the work of Johnson et al. [24]. Measured Sb concentrations in landfill leachates (Swiss bottom ash monofill) were in the range of $1.1 \times 10^{-7}$ to $4.7 \times 10^{-7} \mathrm{~mol} / \mathrm{L}$. The respective $\mathrm{Ca}$ concentrations were in a narrow range between $3.2 \times 10^{-3}$ and $16.2 \times 10^{-3} \mathrm{~mol} / \mathrm{L}$. In the present work, the range of the $\mathrm{Ca}$ concentration was wider $\left(2.8 \times 10^{-3}\right.$ to $\left.68.3 \times 10^{-3} \mathrm{~mol} / \mathrm{L}\right)$ and the $\mathrm{Sb}$ concentrations lower $\left(0.1 \times 10^{-7}-1.3 \times 10^{-7} \mathrm{~mol} / \mathrm{L}\right)$. The lower $\mathrm{Sb}$ release might be due to the slight reduction of $\mathrm{Sb}$ in the tested mineral fraction as a result of enrichment of $\mathrm{Sb}$ in the filter cake, see Table 2.

The solubility of antimony could surely also be influenced by other solid phases controlling the solubility of $\mathrm{Sb}$ that are involved in the present experiment [26] or by other parameters such as alkalinity, carbonate concentration, or $\mathrm{pH}$. The variation of $\mathrm{pH}$ in the lysimeter experiment investigation ranged between 8.5 and 10.5. In this limited $\mathrm{pH}$ range no clear correlation of $\mathrm{pH}$ and $\mathrm{Sb}$ concentration was observable. Influence of $\mathrm{pH}$ on the solubility of $\mathrm{Sb}$ in bottom ash was discussed in the literature [23]. The data from a field study by Sormunen et al. suggest that high Sb concentrations occur when the amount of seepage water is low and at $\mathrm{pH}$ values below 9 [20] (range investigated 8-11.5). However, the authors did not analyze the leachates for $\mathrm{Ca}$. 
The German draft ordinance for reuse of mineral waste [8] defines three recovery categories (HMVA-1, HMVA2, HMVA-3) with decreasing demands on the release of hazardous substances. The limit values for $\mathrm{Sb}$ concentration at an L/S of $2 \mathrm{~L} / \mathrm{kg}$ using column tests or batch tests (DIN 19528 or DIN 19529) are 10,60 and $150 \mu \mathrm{g} / \mathrm{L}$ respectively. The concentration of $\mathrm{Sb}$ in $\mu \mathrm{g} / \mathrm{L}$ at $\mathrm{L} / \mathrm{S} 2 \mathrm{~L} / \mathrm{kg}$ can be retrieved from the value at $\mathrm{L} / \mathrm{S} 2 \mathrm{~L} / \mathrm{kg}$ on the cumulated release curve in $\mathrm{mg} / \mathrm{kg}$ and dividing by $2 \mathrm{~L} / \mathrm{kg}$. The release at $\mathrm{L} / \mathrm{S} 2 \mathrm{~L} / \mathrm{kg}$ for $\mathrm{Sb}$ in the lysimeter experiments is about $0.015 \mathrm{mg} / \mathrm{kg}$ (see Fig. S5 in Supporting Information). Thus, the corresponding concentration can be calculated to $7.5 \mu \mathrm{g} / \mathrm{L}$, close to the limit value of HMVA-1. The limit value would be exceeded if the concentration at the final $\mathrm{L} / \mathrm{S}$ of the experiment $(2.96 \mathrm{~L} / \mathrm{kg})$ was taken for evaluation (release $0.026 \mathrm{mg} / \mathrm{kg}$, resulting concentration $13 \mu \mathrm{g} / \mathrm{L}$ ). In case of $\mathrm{V}$ the limit value of HMVA-1 is also close to the limit value (limit values: 55, 150 and $200 \mu \mathrm{g} / \mathrm{L}$; release at $\mathrm{L} / \mathrm{S} 2 \mathrm{~L} / \mathrm{kg}=0.063 \mathrm{mg} / \mathrm{kg}$, resulting concentration is $31.5 \mu \mathrm{g} / \mathrm{L})$.

Limit value of HMVA-1 for $\mathrm{Sb}$ is exceeded in the standardized column test at an L/S of $2 \mathrm{~L} / \mathrm{kg}$ (DIN 19528) with a concentration of $13 \mu \mathrm{g} / \mathrm{L}$ for $\mathrm{Sb}$ (cumulative release $0.026 \mathrm{mg} / \mathrm{kg}$, see Figure S3 in Supporting Information). With $13 \mu \mathrm{g} / \mathrm{L}$ for $\mathrm{V}$, the concentration is below the limit values.

The results from lysimeter experiment are closer to real field conditions than the column test due to larger sample size and overhead irrigation rather than up-flow conditions. However, for the assessment of the environmental compatibility the column test according to DIN 19528 is legally binding in Germany. Therefore, holding the German limit value of $\mathrm{Sb}$ of HMVA-1 might be problematic for MSWI BA, especially due to the inhomogeneous nature of material. In the present investigation the wet treatment of the ash could have an influence on Sb mobilization because the $\mathrm{Ca}$ content is lower in the treated ash (high Ca content in the filter cake, see Table 2). As explained above concentration of $\mathrm{Ca}$ controls the mobilization of $\mathrm{Sb}$.

\section{Conclusions}

The leaching experiments showed that the aim to reduce $\mathrm{Cl}^{-}$and $\mathrm{SO}_{4}{ }^{2-}$ concentrations in the leachates by the wet treatment technology could be reached [14], in contrast to untreated MSWI BA. More than $60 \%$ of the sulfate is accumulated in the filter cake. This is an important effect when considering the suitability of the intended reuse of such material in construction. This finding might be even more important for the treatment of construction and demolition (C\&D) waste. Sulfate content in C\&D waste is increasing because of the increasing use of building products that contain sulfate. Wet processing could improve the quality of the secondary building material [50], but there are reservations due to greater effort and, in the end, higher cost.

Antimony is present in residues from municipal solid waste incineration [25]. The investigation of the long-term leaching behavior of $\mathrm{Sb}$ was possible only in column and lysimeter experiments and not in batch tests where temporal resolution of the results cannot be obtained. An increase of the $\mathrm{Sb}$ concentration was observed in the lysimeter experiment after $10,000 \mathrm{~h}$ at an $\mathrm{L} / \mathrm{S}$ ratio of $0.75 \mathrm{~L} / \mathrm{kg}$ and in the column experiment at a L/S ratio of 4 . The basic characterization of waste materials according to DIN 19528 [33] with $\mathrm{L} / \mathrm{S}$ ratios of $0.3,1,2$, and $4 \mathrm{~L} / \mathrm{kg}$ is therefore appropriate for revealing complex solubility behavior, rather than the simpler compliance test up to an $\mathrm{L} / \mathrm{S}$ of $2 \mathrm{~L} / \mathrm{kg}$ only. The leaching behavior of $\mathrm{Sb}$ might be critical in view of reuse scenarios with comparably stringent limit values for $\mathrm{Sb}$ such as planned in Germany (10 $\mu \mathrm{g} / \mathrm{L})$ [8], due to increasing release of $\mathrm{Sb}$ with decreasing concentrations of $\mathrm{Ca}$. The cumulative release of $\mathrm{Sb}$ at $\mathrm{L} / \mathrm{S} 2.96 \mathrm{~L} / \mathrm{kg}$ was $0.026 \mathrm{mg} /$ $\mathrm{kg}$ dry matter $(\mathrm{dm})$ and is still increasing. This could be an effect of the removal of the finest fraction by wet treatment which contains approximately $20 \%$ of the initial Ca content. The addition of Ca compounds might not solve the problem, because in the longer term any calcium species will be transformed to sparingly soluble limestone anyway. Perhaps additives containing iron, which lead to adsorption of $\mathrm{Sb}$, to iron hydroxide, or to the formation of Fe-antimonates, could be an alternative [26]. However, further research is needed to identify possible countermeasures for avoiding harmful $\mathrm{Sb}$ release in a later stage of the lifetime of constructions based on waste materials.

Acknowledgements Open Access funding provided by Projekt DEAL. Part of the work was funded with the Central Innovation Programme for SMEs (ZIM) of the German Federal Ministry for Economic Affairs and Energy (HORECA, KF 2201051MF2)

\section{Compliance with Ethical Standards}

Conflict of interest The authors declare that they have no conflict of interest.

Open Access This article is licensed under a Creative Commons Attribution 4.0 International License, which permits use, sharing, adaptation, distribution and reproduction in any medium or format, as long as you give appropriate credit to the original author(s) and the source, provide a link to the Creative Commons licence, and indicate if changes were made. The images or other third party material in this article are included in the article's Creative Commons licence, unless indicated otherwise in a credit line to the material. If material is not included in the article's Creative Commons licence and your intended use is not permitted by statutory regulation or exceeds the permitted use, you will need to obtain permission directly from the copyright holder. To view a copy of this licence, visit http://creativecommons.org/licenses/by/4.0/. 


\section{References}

1. Eurostat: Municipal Waste Statistics: Statistics Explained (23/01/2019). https://ec.europa.eu/eurostat/statistics-explained/ pdfscache/10360.pdf (2019).

2. Di Gianfilippo, M., Hyks, J., Verginelli, I., Costa, G., Hjelmar, O., Lombardi, F.: Leaching behaviour of incineration bottom ash in a reuse scenario: 12 years-field data vs. lab test results. Waste Manage. 73, 367-380 (2018). https://doi.org/10.1016/j.wasma n.2017.08.013

3. Luo, H., Cheng, Y., He, D., Yang, E.-H.: Review of leaching behavior of municipal solid waste incineration (MSWI) ash. Sci. Total Environ. 668, 90-103 (2019). https://doi.org/10.1016/j.scito tenv.2019.03.004

4. Silva, R.V., de Brito, J., Lynn, C.J., Dhir, R.K.: Environmental impacts of the use of bottom ashes from municipal solid waste incineration: a review. Resour. Conserv. Recycl. 140, 23-35 (2019). https://doi.org/10.1016/j.resconrec.2018.09.011

5. Verbinnen, B., Billen, P., Van Caneghem, J., Vandecasteele, C.: Recycling of MSWI bottom ash: a review of chemical barriers, engineering applications and treatment technologies. Waste Biomass Valoriz 8(5), 1453-1466 (2017). https://doi. org/10.1007/s12649-016-9704-0

6. Xuan, D., Tang, P., Poon, C.S.: Limitations and quality upgrading techniques for utilization of MSW incineration bottom ash in engineering applications: a review. Constr. Build. Mater. 190, 1091-1102 (2018). https://doi.org/10.1016/j.conbuildma t.2018.09.174

7. Sormunen, L.A., Kolisoja, P.: Construction of an interim storage field using recovered municipal solid waste incineration bottom ash: field performance study. Waste Manage. 64, 107-116 (2017). https://doi.org/10.1016/j.wasman.2017.03.014

8. BMUB: 4: Referentenentwurf der Mantelverordnung: Verordnung zur Einführung einer Ersatzbaustoffverordnung, zur Neufassung der Bundes-Bodenschutz- und Altlastenverordnung und zur Änderung der Deponieverordnung und der Gewerbeabfallverordnung, Stand: 06.02.2017. (2017)

9. European Commission: M/366 Horizontal Complement to the Mandates for the Development of Horizontal Standardised Assessment Methods for Harmonised Approaches Relating to Dangerous Substances under the Construction Products Directive (cpd) (2005)

10. CEN/TS 16637-3: Construction Products: Assessment of Release of Dangerous Substances: Part 3: Horizontal Up-Flow Percolation test European Committee for Standardization (2016)

11. Dijkstra, J.J., van Zomeren, A., Susset, B.: Technical Principles Underlying Limit Values for Release of Substances for the Percolation Test TS3: Comparison DE and NL. https://www.nen.nl/ Standardization/Join-us/Technical-committees-and-new-subjects/ TC-ConstructionBuilding/CENTC-351-EN.htm (2013)

12. Burnley, S.J.: A review of municipal solid waste composition in the United Kingdom. Waste Manage. 27(10), 1274-1285 (2007). https://doi.org/10.1016/j.wasman.2006.06.018

13. Hyks, J., Astrup, T.: Influence of operational conditions, waste input and ageing on contaminant leaching from waste incinerator bottom ash: a full-scale study. Chemosphere 76(9), 1178-1184 (2009). https://doi.org/10.1016/j.chemosphere.2009.06.040

14. Keulen, A., van Zomeren, A., Harpe, P., Aarnink, W., Simons, H.A.E., Brouwers, H.J.H.: High performance of treated and washed MSWI bottom ash granulates as natural aggregate replacement within earth-moist concrete. Waste Manage. 49, 83-95 (2016). https://doi.org/10.1016/j.wasman.2016.01.010

15. Astrup, T.: Pretreatment and utilization of waste incineration bottom ashes: Danish experiences. Waste Manage. 27(10), 14521457 (2007). https://doi.org/10.1016/j.wasman.2007.03.017
16. Hyks, J., Hjelmar, O.: Utilisation of incineration bottom ash (IBA) from waste incineration: prospects and limits. In: Holm, O., Thome-Kozmiensky, E. (eds.) Removal, Treatment and Utilisation of Waste Incineration Bottom Ash, pp. 11-24. TK Verlag, Neuruppin (2018)

17. van der Sloot, H.A., Kosson, D.S.: Use of characterisation leaching tests and associated modelling tools in assessing the hazardous nature of wastes. J. Hazard. Mater. 207-208, 36-43 (2012). https ://doi.org/10.1016/j.jhazmat.2011.03.119

18. Hjelmar, O., Holm, J., Crillesen, K.: Utilisation of MSWI bottom ash as sub-base in road construction: first results from a largescale test site. J. Hazard. Mater. 139(3), 471-480 (2007). https:// doi.org/10.1016/j.jhazmat.2006.02.059

19. Izquierdo, M., Querol, X., Josa, A., Vazquez, E., López-Soler, A.: Comparison between laboratory and field leachability of MSWI bottom ash as a road material. Sci. Total Environ. 389(1), 10-19 (2008). https://doi.org/10.1016/j.scitotenv.2007.08.020

20. Sormunen, L.A., Kaartinen, T., Rantsi, R.: MSWI BA treated with Advanced Dry Recovery: a field scale study on materials' leaching properties. Int. J. Sustain. Eng. 11(4), 261-271 (2018). https://doi. org/10.1080/19397038.2018.1444679

21. Holm, O., Simon, F.G.: Innovative treatment trains of bottom ash (BA) from municipal solid waste incineration (MSWI) in Germany. Waste Manage. 59, 229-236 (2017). https://doi. org/10.1016/j.wasman.2016.09.004

22. Sormunen, L.A., Kalliainen, A., Kolisoja, P., Rantsi, R.: Combining mineral fractions of recovered MSWI bottom ash: improvement for utilization in civil engineering structures. Waste Biomass Valoriz. 8(5), 1467-1478 (2017). https://doi.org/10.1007/s1264 9-016-9656-4

23. Cornelis, G., Gerven, T.V., Vandecasteele, C.: Antimony leaching from MSWI bottom ash: modelling of the effect of $\mathrm{pH}$ and carbonation. Waste Manage. 32(2), 278-286 (2012). https://doi. org/10.1016/j.wasman.2011.09.018

24. Johnson, C.A., Kaeppeli, M., Brandenberger, S., Ulrich, A., Baumann, W.: Hydrological and geochemical factors affecting leachate composition in municipal solid waste incinerator bottom ash: Part II. The geochemistry of leachate from Landfill Lostorf, Switzerland. J. Contam. Hydrol. 40(3), 239-259 (1999). https:// doi.org/10.1016/S0169-7722(99)00052-2

25. Okkenhaug, G., Almås, Å.R., Morin, N., Halea, S.E., Arp, H.P.H.: The presence and leachability of antimony in different wastes and waste handling facilities in Norway. Environ. Sci. Process Impacts 17(11), 1880-1891 (2015). https://doi.org/10.1039/C5EM00210A

26. Van Caneghem, J., Verbinnen, B., Cornelis, G., de Wijs, J., Mulder, R., Billen, P., Vandecasteele, C.: Immobilization of antimony in waste-to-energy bottom ash by addition of calcium and iron containing additives. Waste Manage. 54, 162-168 (2016). https://doi.org/10.1016/j.wasman.2016.05.007

27. Susset, B., Grathwohl, P.: Leaching standards for mineral recycling materials: a harmonized regulatory concept for the upcoming German Recycling Decree. Waste Manage. 31(2), 201-214 (2011). https://doi.org/10.1016/j.wasman.2010.08.017

28. DIN 66137-2: Determination of solid state density-Part 2: Gaspycnometry (Bestimmung der Dichte fester Stoffe-Teil 2: Gaspyknometrie). German Institute for Standardization (Deutsches Institut für Normung) (2004)

29. DIN 18128: Soil-Investigation and testing-Determination of ignition loss (Baugrund-Untersuchung von BodenprobenBestimmung des Glühverlustes). German Institute for Standardization (Deutsches Institut für Normung) (2002)

30. DIN ISO 11466: Soil quality-Extraction of trace elements soluble in aqua regia (Bodenbeschaffenheit-Extraktion in Königswasser löslicher Spurenelemente). German Institute for Standardization (Deutsches Institut für Normung) (1997) 
31. DIN EN ISO 10693: Soil quality-Determination of carbonate content-Volumetric method (Bodenbeschaffenheit-Bestimmung des Carbonatgehaltes-Volumetrisches Verfahren). German Institute for Standardization (Deutsches Institut für Normung) (2014)

32. Sanusi, A., Wortham, H., Millet, M., Mirabel, P.: Chemical composition of rainwater in Eastern France. Atmos. Environ. 30(1), 59-71 (1996). https://doi.org/10.1016/1352-2310(95)00237-S

33. DIN 19528: Leaching of solid materials-Percolation method for the joint examination of the leaching behaviour of organic and inorganic substances for materials with a particle size upto 32 $\mathrm{mm}$-Basic characterization using a comprehensive column test and compliance test using a quick column test (Elution von Feststoffen-Perkolationsverfahren zur gemeinsamen Untersuchung des Elutionsverhaltens von organischen und anorganischen Stoffen für Materialien mit einer Korngröße bis $32 \mathrm{~mm}$-Grundlegende Charakterisierung mit einem ausführlichen Säulenversuch und Übereinstimmungsuntersuchung mit einem Säulenschnelltest). German Institute for Standardization (Deutsches Institut für Normung) (2009)

34. DIN 19529: Leaching of solid materials-Batch test for the examination of the leaching behaviour of inorganic and organic substances at a liquid to solid ratio of $21 / \mathrm{kg}$ (Elution von Feststoffen-Schüttelverfahren zur Untersuchung des Elutionsverhaltens von anorganischen und organischen Stoffen mit einem Wasser/ Feststoff-Verhältnis von $21 / \mathrm{kg}$ ). German Institute for Standardization (Deutsches Institut für Normung) (2015)

35. DIN EN 12457-2: Characterization of waste-Leaching; Compliance test for leaching of granular and sludges-Part 2: One stage batch test at a liquid to solid ratio of $101 / \mathrm{kg}$ with particle size below $4 \mathrm{~mm}$ (without or with size reduction) (Charakterisierung von Abfällen-Auslaugung; Übereinstimungsuntersuchung für die Auslaugung von körnigen Abfällen und Schlämmen-Teil 2: Einstufiges Schüttelverfahren mit einem Flüssigkeits-/Feststoffverhältnis von $10 \mathrm{l} / \mathrm{kg}$ und einer Korngröße unter $4 \mathrm{~mm}$ (ohne oder mit Korngrößenreduzierung)). German Institute for Standardization (Deutsches Institut für Normung) (2003)

36. DIN EN ISO 5667-3: Water quality-Sampling-Part 3: Guidance on the preservation and handling of water samples (Wasserbeschaffenheit-Probenahme-Teil 3: Anleitung zur Konservierung und Handhabung von Wasserproben). German Institute for Standardization (Deutsches Institut für Normung) (2013)

37. DIN ISO 10390: Soil quality—Determination of $\mathrm{pH}$ (Bodenbeschaffenheit-Bestimmung des $\mathrm{pH}$-Wertes). German Institute for Standardization (Deutsches Institut für Normung) (2005)

38. DIN ISO 11265: Soil quality-Determination of the specific electrical conductivity (Bodenbeschaffenheit-Bestimmung der spezifischen elektrischen Leitfähigkeit). German Institute for Standardization (Deutsches Institut für Normung) (1997)

39. DIN EN ISO 7027: Water quality-Determination of turbidity (Wasserbeschaffenheit-Bestimmung der Trübung). German Institute for Standardization (Deutsches Institut für Normung) (2000)

40. DIN EN ISO 11885: Water quality-Determination of selected elements by inductively coupled plasma optical emission spectroscopy (ICP-OES) (Wasserbeschaffenheit-Bestimmung von ausgewählten Elementen durch induktiv gekoppelte Plasma-Atom-Emissionsspektrometrie (ICP-OES)), German Institute for Standardization (Deutsches Institut für Normung) (2009)

41. DIN EN ISO 10304-1: Water quality-Determination of dissolved fluoride, chloride, nitrite, orthophosphate, bromide, nitrate and sulfate ions, using liquid chromatography of ions-Part 1: Method for water with low contamination (Wasserbeschaffenheit-Bestimmung der gelösten Anionen Fluorid, Chlorid, Nitrit, Orthophosphat, Bromid, Nitrat und Sulfat mittels Ionenchromatographie-Teil 1: Verfahren für gering belastete Wässer). German Institute for Standardization (Deutsches Institut für Normung) (1995)

42. DIN EN ISO 17294-2: Water quality-Application of inductively coupled plasma mass spectrometry (ICP-MS) - Part 2: Determination of selected elements including uranium isotopes (Wasserbeschaffenheit-Anwendung der induktiv gekoppelten PlasmaMassenspektrometrie (ICP-MS) - Teil 2: Bestimmung von 62 Elementen). German Institute for Standardization (Deutsches Institut für Normung) (2005)

43. Dijkstra, J.J., van der Sloot, H.A., Comans, R.N.J.: The leaching of major and trace elements from MSWI bottom ash as a function of $\mathrm{pH}$ and time. Appl. Geochem. 21(2), 335-351 (2006)

44. Simon, F.G., Schmidt, V., Carcer, B.: Alterungsverhalten von MVA-Schlacken. Müll Abfall 27(11), 759-764 (1995)

45. Yin, K., Chan, W.P., Dou, X., Ren, F., Chang, V.W.-C.: Measurements, factor analysis and modeling of element leaching from incineration bottom ashes for quantitative component effects. J. Clean. Prod. 165, 477-490 (2017). https://doi.org/10.1016/j.jclep ro.2017.07.164

46. Krüger, O., Kalbe, U., Berger, W., Simon, F.G., López Meza, S.: Leaching experiments on the release of heavy metals and PAH from soil and waste materials. J. Hazard. Mater. 207-208, 51-55 (2012). https://doi.org/10.1016/j.jhazmat.2011.02.016

47. López Meza, S., Kalbe, U., Berger, W., Simon, F.G.: Effect of contact time on the release of contaminants from granular waste materials during column leaching experiments. Waste Manage. 30(4), 565-571 (2010). https://doi.org/10.1016/j.wasman.2009.11.022

48. Cornelis, G., Gerven, T.V., Snellings, R., Verbinnen, B., Elsen, J., Vandecasteele, C.: Stability of pyrochlores in alkaline matrices: solubility of calcium antimonate. Appl. Geochem. 26(5), 809-817 (2011). https://doi.org/10.1016/j.apgeochem.2011.02.002

49. Parhi, P., Upreti, S., Ramanan, A.: Crystallization of calcium vanadate solids from solution: a metathetic route. Cryst. Growth Des. 10(12), 5078-5084 (2010). https://doi.org/10.1021/cg100 $703 \mathrm{~h}$

50. Weimann, K., Giese, L.B., Mellmann, G., Simon, F.G.: Building materials from waste. Mater. Trans. 44(7), 1255-1258 (2003). https://doi.org/10.2320/matertrans.44.1255

Publisher's Note Springer Nature remains neutral with regard to jurisdictional claims in published maps and institutional affiliations.

\section{Affiliations}

\section{Ute Kalbe $^{1}\left[\right.$ [D Franz-Georg Simon ${ }^{1}(\mathbb{D}$}

Ute Kalbe

ute.kalbe@bam.de
1 Bundesanstalt für Materialforschung und-prüfung (BAM), Unter den Eichen 87, 12205 Berlin, Germany 